\title{
Evaluating the Extrajudicial Measures and Sanctions within the Youth Criminal Justice Act
}

\author{
Kendell Semotiuk \\ Department of Sociology, MacEwan University
}

\begin{abstract}
Since the introduction of the Youth Criminal Justice Act (YCJA), there have been some concerns about the effectiveness of young people utilizing extrajudicial measures and extrajudicial sanctions. This article investigates if the implementation of these measures has created positive impacts for young offenders or if it is equivalent to just "a slap on the wrist." Using a lens of restorative justice, the strengths and weaknesses of youth circles, youth committees, and victim-offender mediation programs are examined. This article explores the roles of those involved within extrajudicial measures and sanctions and addresses the gaps that exist within this section of the YCJA. Ultimately, this article finds that the restorative justice practices of extrajudicial measures and sanctions are effective at supporting young people throughout the legal process. It discovers that the programs offered for young offenders can give them a voice in their situation and create a connection to their community. However, there are changes needed in the areas of consistent data collection, proper fund allocation, and programming availability.
\end{abstract}

\section{Introduction}

Throughout Canadian history, three pieces of legislation have addressed crime in the youth population. In 1908, there was the Juvenile Delinquents Act (JDA), but there were concerns that it did not correctly ensure due process for young people, among other things. In 1984, the Young Offenders Act (YOA) helped implement a juvenile justice system (Bell, 2015, pp. 43-44). However, there were still issues regarding youth crime that needed reform. In 2002, the YOA was replaced with the legislation, the Youth Criminal Justice Act (YCJA). This document allowed more options to support youth and included specifications on extrajudicial measures and sanctions. Under Section 5 (b) of the $Y C J A$, it states that extrajudicial measures should "encourage families of young persons including extended families where appropriate - and the community to become involved in the design and implementation of those measures" (YCJA, 2002).
Furthermore, in regard to extrajudicial sanctions, Section 10 (1) of the YCJA states, "An extrajudicial sanction may be used to deal with a young person alleged to have committed an offence only if the young person cannot be adequately dealt with by a warning, caution or referral" (YCJA, 2002).

Since implementing the new specification of these measures, many young people have been impacted positively. However, the argument can be made that these parameters do not provide enough consequence towards youth crime. So, the question remains, is the use of extrajudicial measures and sanctions equivalent to "doing nothing" or a "slap on the wrist?"

On the one hand, Barbara Tomporowski, Manon Buck, Catherine Bargen, and Valarie Binder (2011), Diane Conrad (2014), Jessica Peters (2019), and Art Eggleton and Raymonde Saint-Germain (2018) highlight the positive impacts within the area of extrajudicial 
measures and sanctions. On the other hand, Mike Howell (2020), Sandra J. Bell (2015), and Rose Ricciardelli, Hayley Crichton, Liam Swiss, Dale C. Spencer and Micheal Adorjan (2017) examine the common gaps in these programs and suggest that there are still more changes needed.

This paper will break down the options that are available to youth involving extrajudicial measures and sanctions. It will inspect the strengths and weaknesses of youth choosing restorative justice. Then, there will be a focus to address the gaps that still exist within the $Y C J A$ and examine the roles of those involved in the process. Ultimately, this paper will conclude with a discussion comparing the positive and negative impacts of extrajudicial sanctions and measures.

\section{The YJCA and Restorative Justice}

Within the context of the YCJA, the alternative justice measures are traditionally associated with restorative justice practices. Eggleton and Saint-Germain (2018) define restorative justice as a greater focus "on the rehabilitation of the offender of a crime, and reconciliation with the victims, and less on punishment. It focuses on repairing harm, the potential for healing in victims, meaningful accountability of offenders and preventing further crime." This unique process allows the youth to have an active role with other individuals, the greater community, and provides an effective method to meet multiple needs at once (Tomporowski et al., 2011, p. 817). These processes are often initiated by the police officers communicating with the youth. Still, they are directed to take other courses of action, such as a verbal or written warning. This kind of approach has positively impacted many youth involved in criminal activities and teaches them the impact of their actions. As Peters (2019) explains, "A lapse in judgment should not define you for the rest of your life...If we don't give people a chance to change their behaviour, they begin to feel they are defined by their behaviour" (Peters, 2019). In matters relating to youth justice, Canada often utilizes standard restorative processes such as youth circles, youth committees, and victim-offender mediation.

\section{Youth Circles, Youth Committees, and Victim- Offender Mediation}

A popular form of extrajudicial measures can be found in youth circles. This process involves the young offender and a range of others, including families, justice professionals, community members, and more. These members collectively agree on an appropriate sentence that is fair to the youth and often relates to the impact the youth's behaviour had on the greater community (Tomporowski et al., 2011, p. 818). This type of dynamic can also be used in other ways such as healing circles, where the meeting focuses on creating a reparation agreement and "promote restoration from the harm done by the behaviour of the young offender" (Bell, 2015, p. 274). While this method can be productive for everyone involved, some are critical of the intervention style of youth circles. Bell (2015), explains that the young offender could experience shaming from those involved and interpret it as a punishment instead of a healing process. To prevent that, the responsibility of the change experienced in the youth circle falls onto everyone involved, not just the young offender or the other group members. (p. 287)

Another form of restorative justice is the implementation of youth committees. These unique groups consist of volunteers involved in discussions about the community's concerns with justice agencies and the police. Additionally, there is a focus on working alongside at-risk youth, educating the public on crucial issues, and becoming involved in matters relating to crime prevention (Tomporowski et al., 2011, p. 818). These groups are more formal than youth circles but adopt a similar principle of involving youth in legal matters pertaining to them. Furthermore, Bell (2015), comments that youth committees "might be the primary decision maker on referrals to [extrajudicial sanctions], or the body responsible for deciding on an [extrajudicial sanctions] program, or both" (p. 277). Since one of the primary objectives of the YCJA is to provide an opportunity for community members to participate in decisions regarding young offenders, youth committees offer a unique role for those that want to make a difference.

A third example of extrajudicial measures can be found in reconciliation/mediation programs. These programs involve "a facilitated dialogue between a victim and an 
offender in which trained, impartial mediators prepare the participants to communicate in a safe and structured setting" (Tomporowski et al., 2011, p. 818). In this process, the young offender faces their victims directly, which can help them realize the full impact of their actions. This process often utilizes practices such as a verbal/written apology, writing essays/letters to individuals involved, financial compensation to the victim, or some alternative form of community service (Bell, 2015, p. 274). Mediation programs add a unique dynamic to the typical offender-victim relationship, not often covered by the media. It requires both parties to be open to this type of agreement and can create meaningful change in certain situations. However, there can be negative implications for the victim that is involved. In some instances, the victim may refuse to face their accuser directly, as it may create a revictimization effect. Tomporowski et al. (2011), addresses this issue by explaining that "all restorative justice programs should be carefully designed with consideration for risk assessment, victim needs, and victim safety" (p. 826). While mediation between the young offender and the victim may not work in every scenario, it can still bring an aspect of closure to both parties involved.

Furthermore, these restorative justice practices have connections to the historical tradition of Indigenous Justice, which often utilizes community-based justice. In one of the news articles, Eggleton and SaintGermain (2018), share a man's story impacted by a restorative justice method. The individual involved had spent the past two decades involved with the prison system and was locked up for many years. However, after participating in a therapeutic group experience connected to his cultural roots, this individual was able to find healing in many areas of his life and is now in university mentoring other students (Eggleton \& SaintGermain, 2018). On the other hand, Howell (2018) examined the impacts of a high school student who went through extrajudicial measures after being charged for creating a racist video that targeted Black people at his school. The young offender attended weekly counselling for months, created an education plan with the police school liaison officer, was suspended from school for five days, and lived in the United States for two weeks with a person of colour (Howell, 2018). However, some of his classmates viewed the alternative justice sentence as insufficient in that it did not reach out to the affected community. In the article, they explain that "there has to be an educational program, or protocols, in place to hold the student accountable for his actions, but none exists" (Howell, 2018). So, while extrajudicial measures and sanctions create meaningful change, other issues remain unaddressed.

\section{Gaps in Extrajudicial Measures and Sanctions}

The first issue regards businesses and a lack of funding for restorative justice community programs. In some situations, "many businesses, particularly large department stores, will not participate in mediation programs, arguing that it costs them too much to take employees away from their job" (Bell, 2015, p. 285). This issue showcases that restorative justice programs are not a one-size-fits-all, and alternative justice methods can have different impacts on business owners and employees. Not surprisingly, a lack of consistent funding can put a limit on the impact on an organization's resources in some communities (Tomporowski et al., 2011, p. 826).

Furthermore, extrajudicial measures and sanctions within the YCJA have different impacts in smaller rural areas, unlike popular urban areas. As Ricciardelli et al. (2017) found in a study of police officers involved in restorative justice programs, "Officers noted they were 'stretched too thin,' and we have observed that staffing levels in rural detachments are low" (Ricciardelli et al., 2017 , p. 608). In matters relating to young offenders, the timing of extrajudicial sanctions and measures is essential. Police officers are a critical part of the process, and being overloaded with many cases could impact their level of involvement in cases such as these.

Another issue found in restorative justice programs is inconsistent data across the provinces and territories in Canada. While the YCJA was widely praised for its changes in youth justice, it still has not been universally embraced across Canada. Due to this, the success of restorative justice programs could be enhanced or limited by the level of acceptance of the philosophy by police officers, crown prosecutors, and other vital roles in related departments (Bell, 2015, p. 288). In a study completed by Tomporowski et al. (2011), they found that "it is not clear how many restorative justice 
programs exist across the country, how many cases are handled with restorative justice, or what the outcomes are for clients who participate in restorative processes." (p. 826). There is typically a relationship between consistent funding and a positive data trend, so inconsistent data could correlate with the previously mentioned funding issue.

Finally, there has been criticism of the extrajudicial measures and sanctions regarding "netwidening" and a possible "revolving door" situation. The term "netwidening" refers to "the suggestion that restorative justice might be used to address relatively minor cases that previously would not have entered the criminal justice system" (Tomporowski et al., 2011, p. 827). The authors (2011), explain further that critics question the level of seriousness young offenders receive for their crime, and if the level of sanctions may have changed if the case had gone to court instead (p. 827). The YCJA has been used in Canada for almost two decades. Still, it is important to continue evaluating the effectiveness of this youth legislation and see what areas could be improved. Furthermore, Bell (2015) elaborates that "under the YCJA, police detain more youth, release more youth on undertakings, and impose more conditions on their release than they did under the YOA" (Bell, 2015, pp. 281-282). So, while the restorative justice framework is practical, it still has certain limitations. Ultimately, while the YCJA could be amended directly, provinces and territories still have an administration role in determining programs regarding extrajudicial sanctions and measures (Bell, 2015, p. 289).

\section{Conclusion}

In conclusion, there are strengths and weaknesses within the extrajudicial measures and sanctions section of the YCJA. While past legislation, such as the $J D A$ and the $Y O A$, tried to address youth crime in different methods, the YCJA plays a vital role in addressing the root issues of youth crime. Instead of harsh punishments, the focus on therapeutic intervention helps establish reconciliation with many young offenders across Canada and their victims. Implementing intentional extrajudicial sanctions and measures can support youth offenders throughout the legal process and set healthy precedents for what comes after. However, reform still needs to be made in the areas of data collection, fund allocation, and programming availability. The topic of extrajudicial measures and sanctions still receives criticism today, but many successes have been attributed to the YCJA. As Peters (2019) explains, "restorative justice is not the easy way out. It's not a slap on the wrist or a way to make excuses. It's about finding the appropriate solution for a particular crime." The unique restorative justice programs can give young offenders a voice in their situation and create a vivid connection to their community.

\section{References}

Bell, Sandra J. (2015). Young Offenders and Youth Justice A Century after the Fact, TopHat, 5th Edition.

Conrad, D. (2014). “Lock 'Em up ...” But WHERE'S the KEY? TRANSFORMATIVE drama with INCARCERATED YOUTH. Journal of Contemporary Issues in Education, $8(2)$.

Eggleton, A., \& Saint-Germain, R. (2018, November 03). Bringing humanity back to the justice system: Why Canada needs more restorative Justice programs | CBC News. Retrieved April 19, 2021, from https://www.cbc.ca/news/canada/manitoba/opinioneggleton-saint-germain-restorative-justice-1.4884839

Howell, M. (2020, June 29). Vancouver creator of racist video lives with person of colour in U.S. for two weeks. Retrieved April 19, 2021, from https://www.bowenislandundercurrent.com/localnews/vancouver-creator-of-racist-video-lives-withperson-of-colour-in-us-for-two-weeks-3124429

Peters, J. (2019, April 12). Generosity of past clients illustrates success of restorative. Retrieved April 19, 2021, from https://www.agassizharrisonobserver.com/community/gen erosity-of-past-clients-illustrates-success-of-restorativejustice/

Ricciardelli, R., Crichton, H., Swiss, L., Spencer, D. C., \& Adorjan, M. (2017). From knowledge to action? The Youth criminal Justice act and use of extrajudicial measures in YOUTH POLICING. Police Practice and Research, 18(6), 599-611.

Tomporowski, B., Buck, M., Bargen, C., \& Binder, V. (2011). Reflections on the past, present, and future of restorative justice in Canada. Alberta Law Review, 48(4),

Youth Criminal Justice Act, SC 2002, c 1, Retrieved April 19, 2021 from https://canlii.ca/t/5441s 